\title{
Analisis Sikap Siswa terhadap Multimedia Pembelajaran Matematika berbasis ICT dengan Model Computer Assited Insruction (CAI)
}

\author{
E F W Puadi ${ }^{1}$ \\ ${ }^{1}$ STKIP Muhammadiyah Kuningan \\ Jl. Moertasiah Soepomo No. 28, Kuningan-Jawa Barat 45511 \\ e-mail: ${ }^{1}$ evanfarhanwahyupuadi@upmk.ac.id
}

\begin{abstract}
This study aims to determine the level of student participation when attending ICT-based mathematics learning along with the factors that influence it. Data was collected in Class VII MTsN 3 Kuningan with 30 students as respondents. The research instrument was in the form of a questionnaire of 20 statement items based on 3 indicators, namely students' responses to ICT media applied in learning, student responses when participating in ICT-based learning, student responses after following ICT based learning. The media used is interactive multimedia using Hipo Animator 5. The research method used is quantitative descriptive with Likert scale analysis. The purpose of this study is to look at student attitudes when participating in ICT-based learning. The results obtained are that most students can use ICT as much as $72.5 \%$, most students can take part in learning well as much as $81.33 \%$, and most students are motivated to learn mathematics after participating in ICT-based learning as much as $60.7 \%$.
\end{abstract}

Keywords (Bold, 10pt Lucida Fax): Learning-Based ICT, Student Participation, Hippani Multimedia Interactive

\begin{abstract}
Abstrak
Penelitian ini bertujuan untuk mengetahui respon siswa ketika mengikuti pembelajaran matematika berbasis ICT beserta faktor-faktor yang mempengaruhinya. Pengambilan data dilakukan di Kelas VII MTs N 3 Kuningan dengan jumlah responden sebanyak 30 siswa Instrumen penelitian berupa angket sebanyak 20 item pernyataan berdasarkan 3 indikator, yaitu respon siswa terhadap media ICT yang diterapkan dalam pembelajaran, respon siswa saat mengikuti pembelajaran berbasis ICT, respon siswa setelah mengikuti pembelajaran berbasis ICT. Media yang digunakan adalah multimedia interaktif menggunakan Hipo Animator 5.. Metode penelitian yang digunakan adalah deskriptif kuantitatif dengan melihat presentasi respon. Tujuan dari penelitian ini adalah untuk melihat sikap siswa ketika mengikuti pembelajaran berbasis ICT. Hasil penelitian yang diperoleh yakni sebagain besar siswa dapat menggunakan media ICT sebanyak 72,5\%,
\end{abstract}




\section{Hipotenusa}

Journal of Research Mathematics Education VOL. 3 NO.1 2020

sebagian besar siswa dapat mengikuti pembelajaran dengan baik sebanyak $80 \%$, dan sebagain besar siswa termotivasi untuk mempelajari matematika setelah mengikuti pembelajaran berbasis ICT sebanyak $60 \%$.

Kata kunci: Pembelajaran Berbasis ICT, sikap siswa, Multimedia Interaktif Hipo Animator. 


\section{PENDAHULUAN}

Pembelajaran matematika tidak hanya membutuhkan komponen kognitif secara parsial, akan tetapi perlu ditunjang pula oleh aspek lainya seperti psikomotorik dan afektif [1]. Kedua aspek penunjang tersebut berpengaruh terhadap sikap siswa saat mengikuti pembelajaran matematika. Pembelajaran didalam kelas pada umumnya tidak memperhatikan kebutuhan siswa, akan tetapi pelaksanaan pembelajaran lebih menekankan pada tercapainya kurikulum yang sudah ditetapkan oleh pemerintah [2]. Kondisi seperti ini menyebabkan hilangnya kreatifitas guru saat mempersiapkan proses pembelajaran. seharunya, perencanaan pembelajaran senantiasa memperhatikan kebutuhan siswa, sehingga guru dituntut untuk berkreasi dan melakukan inovasi pembelajaran.

Proses pembelajaran matematika memerlukan inovasi yang dapat mengakomodir kebutuhan siswa saat mengikuti pembelajaran di kelas. Perkembangan teknologi sudah memasuki era 4.0 atau era revolusi industri pada tahap yang lebih tinggi. Kondisi ini, mempengaruhi berbagai aspek kehidupan manusia termasuk pendidikan. Sekolah sebagai penyelenggara pendidikan formal dalam pelaksanaannya diatur oleh undang-undang yang ditetapkan pemerintah. Pada dasarnya, pemerintah telah merancang kurikulum yang dipersiapkan untuk membekali siswa dalam menghadapi persaingan global. Sebagaimana tertera dalam Undang-undang Republik Indonesia nomor 20 tahun 2003 tentang sistem pendidikan nasional, sistem pendidikan nasional harus mampu menjamin pemerataan kesempatan pendidikan, peningkatan mutu serta relevansi dan efisiensi manajemen pendidikan untuk menghadapi tantangan sesuai dengan tuntutan perubahan kehidupan lokal, nasional, dan global sehingga perlu dilakukan pembaharuan pendidikan secara terencana, terarah, dan berkesinambungan [3]. Langkah penting yang perlu dilakukan oleh guru saat mempersiapkan pembelajaran adalah 
dengan memanfaatkan teknologi sebagai media dalam menyampaikan materi pembelajaran.

Pemanfaatan teknologi dalam pembelajaran telah banyak diteliti dampak dan manfaatnya. Sebagaimana kajian yang telah dilakukan oleh M Khairani bahwa bahwa media pembelajaran dapat mengubah pembelajaran yang abstrak, siswa yang mengalami kendala dalam memahami konsep matematika akan terbantu oleh adanya visualisasi melalui media pembelajaran [4]. Selanjutnya, pengembangan media pembelajaran dalam penelitian lain, kususnya pada materi geometri dapat dirancang dengan menggunakan platform android, beberapa keunggulan yang diperoleh melalui platform ini yaitu, menyajikan materi jarak dalam ruang dimensi tiga dengan menarik dan mudah dipahami [6]. Selain dapat diterapkan pada konsep geometri, media pembelajaran dengan memanfaatkan teknologi dapat pula diterapkan pada konsep matematika yang lain, sehingga media pembelajaran memiliki pengaruh besar terhadap peningkatan prestasi siswa [7]. Pengaruh media tersebut disebabkan oleh adanya respon siswa yang positif terhadap pembelajaran matematika.

Respon siswa adalah tanggapan; reaksi; jawaban. Tanggapan merupakan salah satu fungsi kejiwaan yang dapat diperoleh individu setelah pengamatan selesai dilakukan [5] Siswa yang mengikuti pembelajaran dengan menggunakan media pembelajaran akan memiliki kesan berbeda, dibandingakan dengan siswa yang mengikuti pembelajaran tanpa bantuan media pembelajaran. hal ini diperkuat oleh beberapa hasil penilitian, diantaranya mengungkapkan bahwa minat dan kebiasaan memiliki pengaruh yang positif secara bersamaan terhadap hasil belajar [8]. Minat siswa muncul dari kesan yang positif , jika kesan siswa kurang baik maka akan menjadikan minat siswa berkurang.

Dari pemaparan terdahulu, maka peneliti mencoba untuk mengkonfirmasi sejauh mana media pembelajaran dapat menimbulkan respon positif siswa setelah melakukan pembelajaran. media pembelajaran yang digunakan adalah produk multimedia rancangan 


\section{Hipotenusa}

Journal of Research Mathematics Education VOL.3 NO.1 2020

dari software hipo animator 5 dan diterapkan pada materi statistika untuk penyajian data. Unsur kebaruan yang dimiliki dalam penelitian ini adalah penggunaan software Hipo animator 5 untuk membuat multimedia pembelajaran, dimana software ini memiliki fleksibilitas dalam penggunaannya. Diantara kemudahan yang diperoleh dari software ini adalah support dengan html 5 yang merupakan bahasa pemrograman utama untuk web. Sehingga, produk yang dihasilkan oleh software ini, dapat dengan mudah diakses oleh siswa baik online maupun online. Salah satu media pembelajaran yang tepat untuk menerapkan media berbasis teknologi adalah Model pembelajaran Computer Assisted Instruction (CAI). Model pembelajaran ini, akan membutuhkan perangkan komputer. Siswa dituntut untuk dapat mengoperasikan komputer khususnya terkait media yang sudah disiapkan.

Dari pertimbangan tersebut, apakah hadirnya inovasi ini dapat diterima oleh siswa, dan berpengaruh terhadap respon siswa setelah mengikuti pembelajaran. oleh sebab itu, munculah ketertarikan peneliti untuk melihat lebih jauh Sikap Siswa terhadap Multimedia Pembelajaran Matematika berbasis ICT dengan Model Computer Assited Insruction (CAI).

\section{METODE PENELITIAN}

Pada bagian ini, anda diminta menjelaskan: (1) tunjuan penelitian, Penelitian ini bertujuan untuk melihat sikap siswa ketika mengikuti pembelajaran berbasis ICT dengan memanfaatkan multimedia interaktif yang dirancang menggunakan software Hipo Animator 5. Sikap siswa tersebut terntunya dibatasi pada ruang lingkup pengamatan berdasarkan indikator yang ditentukan oleh peneliti (2) subjek dan lokasi penelitian, Subjek penelitian siswa kelas VII MTs N 3 Kuningan yang berada di Kelurahan Cigugur Kecamatan Kuningan Kabupaten Kuningan(3) metode penelitian, Metode 
penelitian yang digunakan adalah deskriptif kuantitatif, yakni dengan menganalisis hasil angket memakai skala likert, kemudian dilihat rentang sikap dari hasil angket yang telah diisi oleh responden

Penelitian ini merupakan penelitian deskriptif yang bertujuan untuk mendeskripsikan dan menganalisis respon siswa saat mengikuti pembelajaran matematika berbasis ICT. Persentase respon siswa dihitung dengan rumus sebagai berikut:

Presentasi Respon $=\frac{\text { Jumlah Skor }}{\text { Jumlah Skor Maksimal }} \times 100$

Hasil persentase respon tersebut diubah menjadi data kualitatif dengan kriteria sebagaimana ditunjukkan pada Tabel 1.

Tabel 1. Kriteria respon siswa terhadap pembelajaran matematika bebasis ICT

\begin{tabular}{ccc}
\hline Presentase & Kategori \\
\hline $81,25 \leq \mathrm{x}<100$ & Sangat Baik \\
$62,5 \leq \mathrm{x}<81,25$ & Baik \\
$43,75 \leq \mathrm{x}<62,5$ & Kurang Baik \\
\hline
\end{tabular}

(Fatmawati, 2016)

Pengambilan data menggunakan instrument angket dengan 20 item pernyataan yang terdiri dari pernyataan positif dan negatif. Angket tersebut dibagikan kepada siswa sebagai responden. Penyusunan angket dilakukan berdasarkan indikator penliaian sikap. Kemudian hasilnya menjadi data respon siswa untuk dianalisis dan diperoleh gambaran sikap siswa terhadap pembelajaran dengan menggunakan model CAI dan penerapan multimedia dalam pelaksanaannya. 


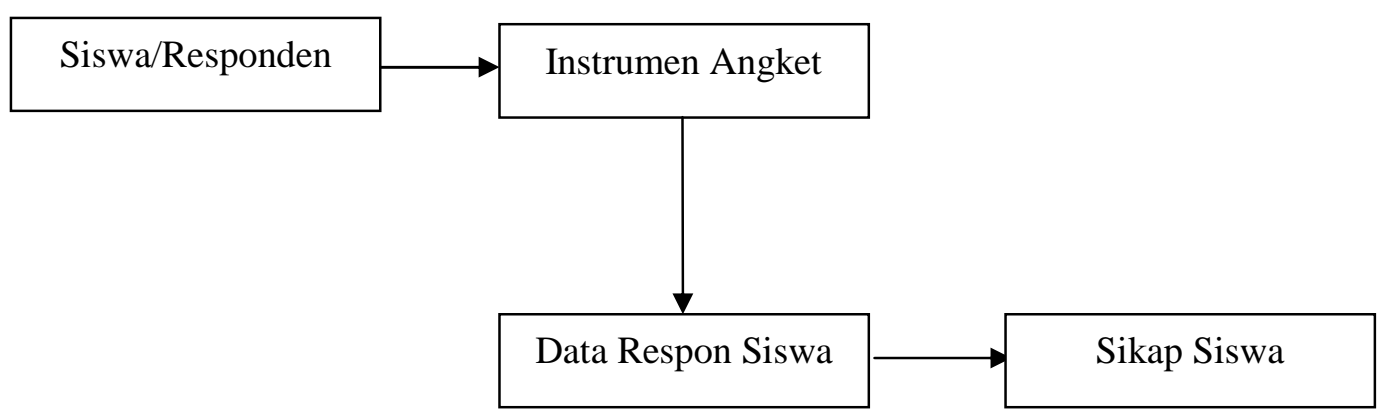

Gambar 1 Bagan Prosedur Penelitian

\section{HASIL DAN PEMBAHASAN}

Hasil penelitian ini, dibahas berdasarkan indikator angket yang telah disusun. Setiap item pernyataan diturunkan dari indikator, sehingga menjadi dasar untuk menggambarkan sikap siswa. Hasilnya dianalisis berdasarkan rumus presentasi sikap siswa. Angket respon siswa diberikan sesaat setelah pembelajaran menggunakan model pembelajaran berbasis ICT. Data hasil respon siswa ditunjukkan pada Tabel 2.

Tabel 2. Hasil Respon Siswa Berdasarkan Indikator

\begin{tabular}{llc}
\hline No. & \multicolumn{1}{c}{ Indikator } & $\begin{array}{c}\text { Rerata } \\
\text { Skor }\end{array}$ \\
\hline 1 & $\begin{array}{l}\text { respon siswa terhadap media ICT yang diterapkan } \\
\text { dalam pembelajaran }\end{array}$ & 72,5 \\
2 & $\begin{array}{l}\text { respon siswa saat mengikuti pembelajaran berbasis } \\
\text { ICT }\end{array}$ & 80 \\
3. & $\begin{array}{l}\text { respon siswa setelah mengikuti pembelajaran } \\
\text { berbasis ICT }\end{array}$ \\
\hline
\end{tabular}

Adapun perbandingan respon positif siswa pada indikator pertama, yaitu 72,5 memiliki respon positif dan 27,5 memiliki respon 


\section{Hipotenusa}

Journal of Research Mathematics Education VOL.3 NO.1 2020

negatif. Untuk lebih jelasnya, digambarkan pada diagram batang berikut ini

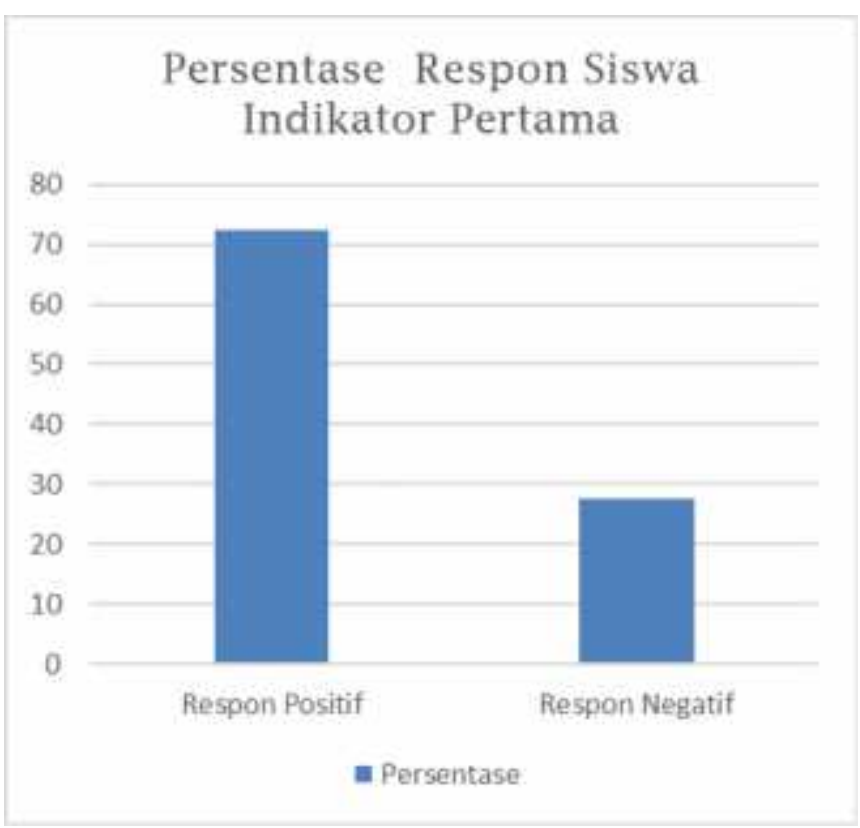

Gambar 1 Grafik perbandingan respon siswa berdasarkan indikator pertama

Terlihat bahwa, jumlah presentasi untuk sikap positif lebih besar $72,5 \%$ dibandingkan dengan respon negatif siswa sebasar $27,5 \%$. Hal ini menunjukan bahwa sebagian besar siswa memiliki respon positif terhadap media pembelajaran yang digunakan pada model pembelajaran CAI.

Media pembelajaran yang digunakan adalah multimedia interaktif yang dirancang menggunakan hippani atau hippo animator 5 . Demikian seterusnya pada indikator kedua dan ketiga. Model pembelajaran CAI yang diterapkan menggunakan multimedia interaktif yang dirancang menggunakan software Hippani 5.

Adapun perbandingan respon positif siswa pada indikator kedua, yaitu 80 memiliki respon positif dan 20 memiliki respon negatif. Untuk lebih jelasnya, digambarkan pada diagram batang berikut ini 


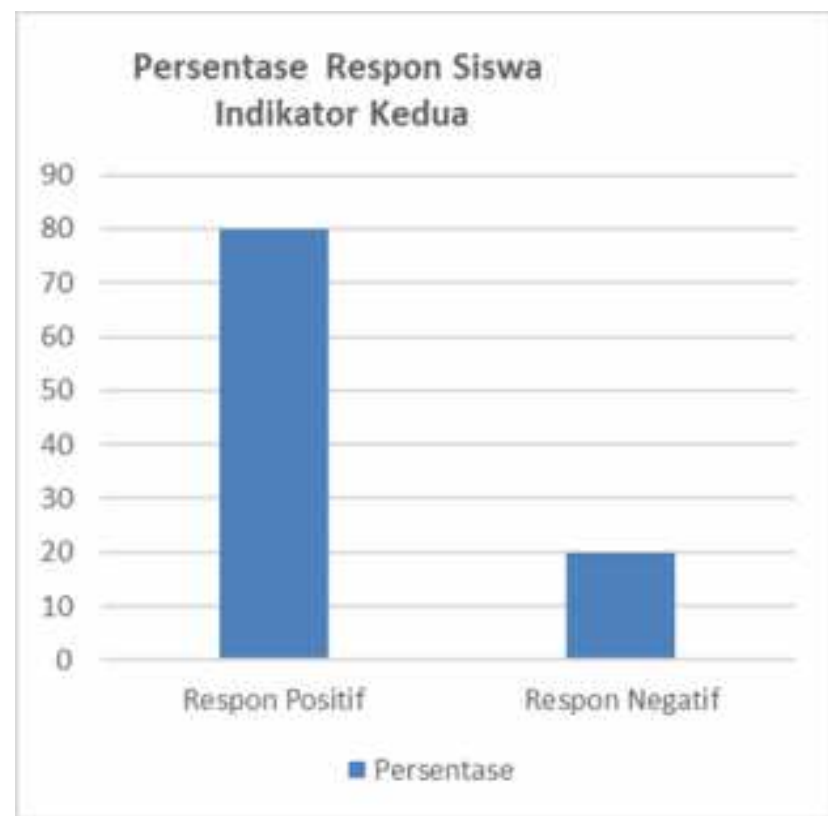

Gambar 2 Grafik perbandingan respon siswa berdasarkan indikator kedua

Terlihat bahwa, jumlah presentasi untuk sikap positif lebih besar $80 \%$ dibandingkan dengan respon negatif siswa sebasar $20 \%$. Hal ini menunjukan bahwa sebagian besar siswa dapat mengikuti pembelajaran yang menerapkan model pembelajaran CAI.

Pengertian lain dari deskripsi hasil angket siswa pada indikator kedua yakni, siswa pada umumnya dapat menggunakan multimedia yang telah disediakan untuk mengikuti pembelajaran. hal ini tentunya didukung pula oleh sarana sekolah dalam mempersiapkan perangkat komputer sebagai penunjang diterapkannya model pembelajaran berbasis ICT dengan media pembelajaran berupa multimedia interaktif.

Adapun perbandingan respon positif siswa pada indikator ketiga, yaitu 60 memiliki respon positif dan 40 memiliki respon negatif. Untuk lebih jelasnya, digambarkan pada diagram batang berikut ini 


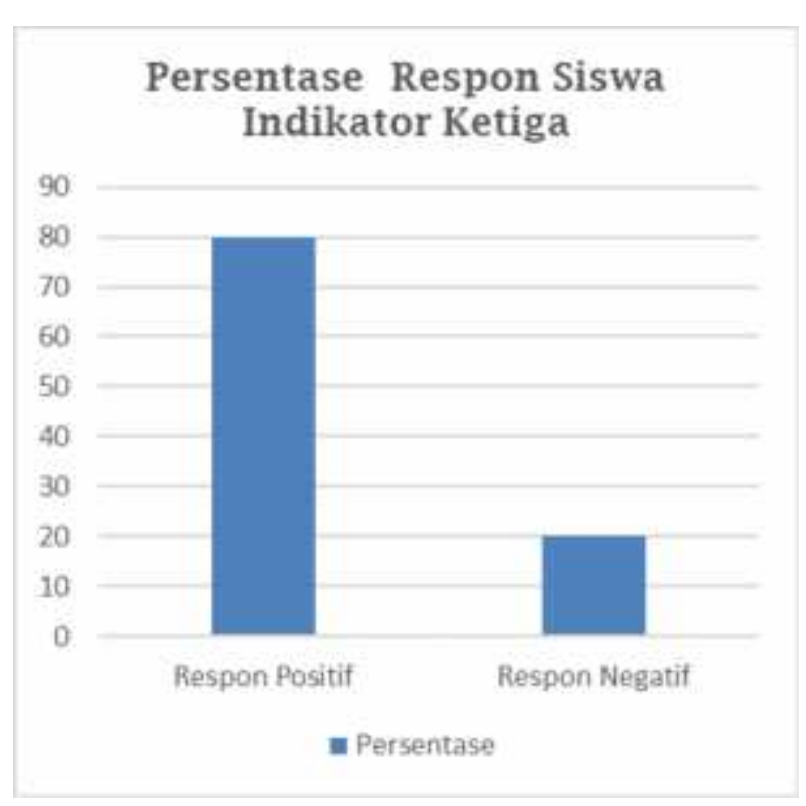

Gambar 3 Grafik perbandingan respon siswa berdasarkan indikator ketiga

Terlihat bahwa, jumlah presentasi untuk sikap positif lebih besar $60 \%$ dibandingkan dengan respon negatif siswa sebasar $40 \%$. Hal ini menunjukan bahwa lebih dari setengah jumlah siswa termotivasi setelah mengikuti pembelajaran yang menerapkan model pembelajaran CAI.

Dari ketiga indikator tersebut, diperoleh gambaran bahwa siswa sebagian besar dapat menjalankan media berupa multimedia interaktif, dapat mengikuti model pembelajaran menggunakan multimedia interaktif dan memiliki respon positif seletah mengikuti pembelajaran. respon positif tersebut merupakan bentuk dari motivasi belajar siswa. 


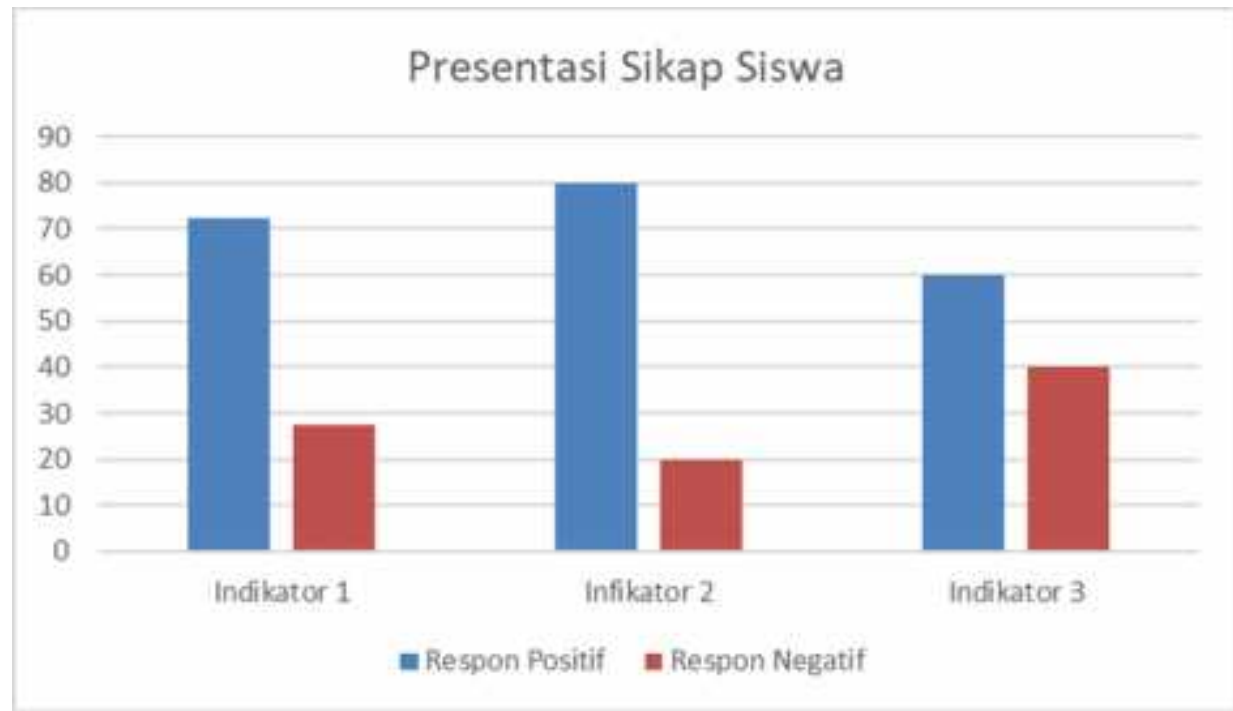

Gambar 4 Grafik presentasi sikap siswa berdasarkan

\section{KESIMPULAN DAN SARAN}

Sebagian besar siswa memiliki respon positif terhadap media pembelajaran yang digunakan pada model pembelajaran CAI. siswa pada umumnya dapat menggunakan multimedia yang telah disediakan untuk mengikuti pembelajaran. hal ini tentunya didukung pula oleh sarana sekolah dalam mempersiapkan perangkat komputer sebagai penunjang diterapkannya model pembelajaran berbasis ICT dengan media pembelajaran berupa multimedia interaktif. siswa sebagian besar dapat menjalankan media berupa multimedia interaktif, dapat mengikuti model pembelajaran menggunakan multimedia interaktif dan memiliki respon positif seletah mengikuti pembelajaran

Dengan demikian disarankan kepada guru khusus pada tingkat SMP untuk melakukan inovasi pembelajaran menggunakan multimedia interaktif. Adapun motivasi siswa setelah pembelajaran perlu adanya upaya lain, sehingga hasil yang diharapkan dapat lebih baik dan optimal. 
[1] Baridin, B. (2018). Pengaruh Kompetensi Guru dan Strategi Pembelajaran Terhadap Mutu Pendidikan di MTs Negeri 2 Brebes. Jurnal Kependidikan, 6(1), 123-144.

[2] Fatmawati, A. (2016). Pengembangan Perangkat Pembelajaran Konsep Pencemaran Lingkungan Menggunakan Model Pembelajaran Berdasarkan Masalah Untuk SMA Kelas X. Edu Sains: Jurnal Pendidikan Sains \& Matematika, 4(2).

[3] Kemendiknas. (2003). Undang-undang Republik Indonesia nomor 20 tahun 2003 tentang sistem pendidikan nasional. Jakarta: Pemerintah Republik Indonesia.

[4] Khairani, M., \& Febrinal, D. (2016). Pengembangan media pembelajaran dalam bentuk macromedia flash materi tabung untuk SMP kelas IX. Jurnal Ipteks Terapan, 10(2), 95-102.

[5] Nasional, D. P. (2008). Kamus besar bahasa Indonesia. Jakarta: Balai Pustaka.

[6] Purbasari, R. J., Kahfi, M. S., \& Yunus, M. (2013). Pengembangan aplikasi android sebagai media pembelajaran matematika pada materi dimensi tiga untuk siswa SMA kelas X. Jurnal Online Universitas Negeri Malang, 1(4), 1-10.

[7] Sapta, A. (2007). PENGARUH MEDIA PEMBELAJARAN DAN PERSEPSI SISWA PADA PEMBELAJARAN MATEMATIKA TERHADAP HASIL BELAJAR MATEMATIKA. UNIMED.

[8] Siagian, R. E. F. (2015). Pengaruh minat dan kebiasaan belajar siswa terrhadap prestasi belajar matematika. Formatif: Jurnal Ilmiah Pendidikan MIPA, 2(2).

[9] Sibuea, R. I. (2014). PENGEMBANGAN BAHAN AJAR MATEMATIKA MELALUI PENDEKATAN MATEMATIKA REALISTIK BERBASIS KURIKULUM 2013 UNTUK MENINGKATKAN KEMAMPUAN KOMUNIKASI MATEMATIS SISWA DIKELAS VII SMP TRI JAYA MEDAN. UNIMED. 